\title{
Novel mutations in the toll like receptor genes cause hyporesponsiveness to Mycobacterium avium subsp. paratuberculosis infection
}

\author{
Mangesh Bhide ${ }^{1,2^{*}}$, Rastislav Mucha ${ }^{2}$, Ivan Mikula jr. ${ }^{1}$, Lucia Kisova ${ }^{1}$, Rostislav \\ Skrabana $^{2}$, Michal Novak ${ }^{2}$, Ivan Mikula sr., ${ }^{1,2}$ \\ ${ }^{1 *}$ Laboratory of Biomedical Microbiology and Immunology, \\ University of Veterinary Medicine, Komenskeho-73, Kosice, Slovakia.

$$
\begin{gathered}
\text { Phone - + } 421904461705 \\
\text { Fax - + } 421556323666
\end{gathered}
$$$$
\text { E.mail - mangeshbhide@hotmail.com }
$$ \\ ${ }^{2}$ Institute of Neuroimmunology,
} Slovak Academy of Sciences, 84245 Bratislava, Slovakia

Running title - TLR gene mutations cause hyporesponsiveness to MAP 


\begin{abstract}
Toll like receptors play a central role in the recognition of pathogen associated molecular patterns (PAMPs). Mutations in TLR1, TLR2 and TLR4 genes may change the PAMP reorganization ability which causes altered responsiveness to the bacterial pathogens. A case control study, performed to assess the association between TLR gene mutations and susceptibility to Mycobacterium avium subsp. paratuberculosis (MAP), revealed novel mutations (TLR1 - Ser150Gly and Val220Met; TLR2 - Phe670Leu) that hindered either PAMP recognition or further downstream TLR pathway activation. A cytokine expression experiments (IL-4, IL-8, IL-10, IL-12 and IFN- $\gamma$ ) in the challenged mutant and wild type moDCs (mocyte derived dendritic cells) confirmed the negative impact of these mutations and altered TLR downstream activation. Further In silico analysis of the TLR1 and TLR4 ectodomains (ECD) revealed the polymorphic nature of the central ECD and irregularities in the central LRR motifs. The most critical positions that may alter the pathogen recognition ability of TLR were: the $9^{\text {th }}$ amino acid position in LRR motif (TLR1, LRR10) and $4^{\text {th }}$ residue downstream to LRR domain (exta LRR region of TLR4). The study describes novel mutations in the TLRs and presents their association with the MAP infection.
\end{abstract}

Key words - Mycobacterium avium subsp. paratuberculosis, TLR1, TLR 2, TLR4, sheep, mutation, 


\section{Introduction}

A conserved set of receptors called pattern-recognition receptors has immense importance in the innate immune system. A role of Toll like receptors (TLRs), members of mammalian pattern-recognition receptors, has been elaborated in recent years ${ }^{1-5}$. They are the key components of pathogen recognition mechanism initiating inflammatory responses brought about by microbes or microbial cell components ${ }^{6,7}$. TLR family possesses 14 distinct members identified so far, expressed by epithelial and endothelial cells as well as leukocytes. TLRs are type-I transmembrane receptors composed of an ectodomains (ECDs), a short transmembrane region, and an intracellular signaling domain that shares homology with that of the IL-1 receptor ${ }^{8}$. TLR mediated cellular activation occurs following the recognition of specific microbial components by the ECD ${ }^{8}$. These receptors act as the sensors for viral, bacterial and fungal structures, for example, TLR3 recognizes viral dsDNA ${ }^{9}$, TLR7 and TLR8 recognize the ssRNA ${ }^{10-12}$, TLR5 triggers immune signal by detecting flagellin, and CpG DNA is a ligand for TLR9 ${ }^{13}, 14$. Toll like receptors focused in this study, TLR1, TLR2 and TLR4, recognize bacterial cell components. TLR2 has been shown to mediate the innate immune response to ligands derived from Mycoplasma, Borrelia, Treponema, Chlamydia, yeasts and parasites ${ }^{15-20}$. TLR2 and TLR4 are critical in the immune response to Gram positive and negative bacteria $^{21}$. Indeed, TLR1 and TLR6 in association with TLR2 (TLR1-TLR2 and TLR2TLR6 heteromers) recognize a variety of bacterial cell wall components ${ }^{22-25}$.

Mutations in the coding region of human TLRs are linked with the altered PAMP recognition ability, signal transduction or innate immune activation in general ${ }^{19,26-30}$. Mutations in TLR1 gene are associated with the variantion in immune response to 
lipopeptides ${ }^{27}$, increased susceptibility to invasive aspergillosis ${ }^{31}$ or impaired innate immune sensing of microbial cell wall components ${ }^{32}$. TLR2 and TLR4 gene polymorphisms are also often linked with increased risk to infections like tuberculosis ${ }^{15}$, ${ }^{33}$, Mycobacterium leprae ${ }^{34,35}$, pneumococci or malaria ${ }^{30,36}$, urinary tract infections ${ }^{37}$ and disease conditions like periodontitis ${ }^{38}$, acute rheumatic fever ${ }^{39}$ and Crohn's disease 40.

The aim of the study was to screen the ovine population for the mutations in TLR1, TLR2 and TLR4 genes, and to assess their possible association with MAP susceptibility. 


\section{Results}

\section{Presence of MAP in the sheep population}

82 sheep $(11.3 \%)$ were found infected with MAP, tested with ELISA as well as IS900 based PCR. MAP infected $(\mathrm{n}=82)$ and non-infected healthy $(\mathrm{n}=838)$ sheep were studied further for the presence of TLR mutations.

\section{TLRs gene mutations and MAP infection}

None of the earlier cited mutations in TLR2 and TLR4 (TLR2 - Pro681His, Arg677Trp, Arg753Gln, and TLR4 - Asp299Gly, Thr399Ile) were found in the sheep population. However, the sequence analysis revealed novel polymorphisms in ovine TLR2 and TLR4 (Tables 2 - 4). We found a novel mutation Phe670Leu in TLR2 gene in 56 sheep infected with MAP. $25 \%$ of the subjects carrying this mutation in heterozygous state $(\mathrm{OR}-4.5)$ and $7.6 \%$ subjects carrying this mutation in homozygous state (OR - 1.1) were MAP infected (Table 3). Another mutation in TLR2 gene at the base pair 2037 (T to C) exchanging leucine against proline at residue 679 was found in 54 subjects infected with MAP. Both these mutations are located in highly conserved region of TLR2 gene near the known mutation Arg677Trp.

Novel mutation in TLR4 gene associated with increased susceptibility to MAP infection was located at the base pair T1066C exchanging phenylalanine against leucine (OR - 1.64). Other mutations found in TLR2 and TLR4 genes in this study (Tables 3 and 4) had no association with the increased susceptibility to MAP infection.

Two mutations (Ser150Gly and Val220Met) in TLR1 gene were found in 74 subjects of that 32 sheep $(43.2 \%)$ were MAP infected. Both these mutations were occurred simultaneously in all 74 subjects. Apart from these two mutations we found 
novel mutations in TLR1 at the base pairs: 418 (A to G), 431 (A to T), 508 (T to C), 601 (A to $\mathrm{T}$ ) and 603 (T to $\mathrm{C}$ ) (Table 2).

\section{TLR expression in mutant moDCs}

Representative MAP infected sheep showing mutations in TLR genes $(n=6$ per mutation; mutant moDCs) and healthy sheep without TLR mutations ( $\mathrm{n}=6$; wild type moDCs) were targeted for TLR mRNA expression. We observed increase in the TLRs expression by 3-6 folds in activated moDCs compared to the non activated control moDCs (data not presented). However, when mutant and wild type moCDs were challenged with LPS or MAP whole cell lysate, the antigen dependent induction of TLRs was not observed $(\mathrm{P}>0.05$; Figure 1$)$. Expression of $\beta$-actin was unchanged throughout the TLR mRNA expression experiments (data not shown).

\section{TLR mutations and cytokine mRNA production}

IFN- $\gamma$, IL-10 and IL-12 were the abundantly expressed cytokines in the wild type moDCs when challenged with LPS and MAP whole cell lysate. Increase in the cytokines expression, except IL-4, in challenged wild type moDCs was 6 to 9 folds than in nonchallenged moDCs (data not presented). In general, MAP cell lysate caused higher cytokine response in moDCs than LPS. Expression of IL-8 was lower than other abundantly expressed ILs, whereas IL-4 was neither detected in ovine wild type nor in mutant moDCs (Figure 2).

Expression of IL-10 in challenged TLR1 mutant (Gly150, Met220) moDCs was significantly lower $(\mathrm{P}<0.05)$ than in challenged wild type moDCs. This cytokine was also under expressed in mutant moDCs carrying TLR2 Leu670 mutation (Figure 2 panel A 
and B). Another two cytokines, IFN- $\gamma$ and IL-12, were under expressed in the mutant moDCs carrying TLR1 (Gly150, Met220) and TLR2 (Leu670) mutations compared with wild type moDCs (Figure B panel A, B and E). Interestingly IL-8 mRNA expression was unchanged in TLR1 mutant moDCs, but significantly lowered $(\mathrm{P}<0.05)$ in TLR2 Leu670 moDcs. No altered cytokine expression was noticed in challenged moDCs carrying TLR2 Phe679 and TLR4 Leu356 mutations (Figure 2 panel C and D).

\section{TLR1 and TLR4 LRR motifs: In silico analysis}

Central core of regular LRR motif is LxxLxLxxNxL, wherein ' $x$ ' is any amino acid, 'L' is Leu, Ile, Val or Phe, and ' $N$ ' is Asn, Thr, Ser or Cys. Certain irregularities were observed within the LRR motifs of TLR1 (LRR8 and LRR11) and TLR4 (LRR13 and LRR14) (Figure 3 panel A and B). A central part of TLR1 ectodomain (LRR10) found prone to missense mutations and more irregular than other LRRs. TLR1 mutations Gly150 and Met220, causing hyporesponsiveness to MAP infection, were located within the extra-LRR region and intra-LRR motif respectively (Figure 3 panel A). Met220 mutation was found in LRR10 motif at the $9^{\text {th }}$ amino acid position $\left(\operatorname{LxxLxLxx} \underline{\mathbf{N}^{\text {9th }}} \times L\right.$; Figure 3 panel C).

We also present LRR motif structure of TLR4 ECD spanning earlier described Asp299Gly and Thr399Ile mutations. Both mutations were found in extra LRR region (Figure 3 panel B) in human TLR4. In the sheep population TLR4 Asp299Gly and Thr399Ile mutations were absent; however, the amino acid position 299 was occupied by asparagine and 399 by theronine. 


\section{Discussion}

Recent studies have reported the involvement of TLRs in the innate immune response against MAP ${ }^{45,46}$. Mycobacterial cell wall components like lipomannan, lipoarabinomannan, phosphatidylinositol dimannoside and a 19-kDa lipoprotein are the agonists for the TLR1 and TLR2 receptors ${ }^{21,47-49}$, while TLR4 recognizes live $M$. tuberculosis ${ }^{50}$. TLRs mediated downstream pathway leads to the up-regulation of interleukins, chemokines, costimulatory molecules, adhesions and pro-inflammatory/antiinflammatory cytokines ${ }^{42,51}$. Activation of TLRs not only direct the phagocytic cells to process and present the antigens but also it induces their self expression ${ }^{42}$. TLR dependent activation of macrophages leads to the phagocytosis and secretion of inflammatory modulators, whereas activated dendritic cells are directed towards the uptake, its processing and presentation of antigen to T cells ${ }^{52}$.

The heterozygous variant may give ambiguous results. Neither the hyporesponsiveness, nor the reduced cytokine response to TLR agonists was observed in heterozygous TLR4-Asp299Gly ${ }^{53-55}$ and heterozygous TLR2-Arg753Gln cells ${ }^{15,33-35}$. Hence, in the present study the in vitro challenging was carried out only in moDCs carrying mutations in homozygous state.

In this study the IL12, IFN- $\gamma$ and IL-10 were expressed abundantly in the activated wild type moDCs. Others ${ }^{42,52}$ have reported that moDCs primarily produce IL12 upon triggering by the TLR agonists, while macrophages produce IL-10. However, we found no significant difference between the expression levels of IL-12 and IL-10 mRNAs in the activated wild type moDCs. In line with the previous reports ${ }^{42,56}$ we also found mixed Th1/Th2 cytokine response of moDCs to TLR agonists. IL-12 and IFN- $\gamma$ are the 
Th1 cytokines while IL-10 belongs to the Th2 class. IL-4 was the least expressed Th2 interleukin in the activated wild type as well as mutant moDCs in this study. Earlier reports ${ }^{57,58}$ suggest the structural and functional similarities between IL-13 and IL-4. The lowest expression of IL-4 may be because of its substitution by IL-13. It is important to note that IL-8 mRNA expression was significantly hindered in activated mutant moDCs possessing TLR2 Leu670 mutation, but not in the activated mutant moDCs caring TLR1 mutations. This indicates that IL-8 expression might be TLR2 dependent. Supportive data was published earlier, wherein micrococci and peptidoglycan induced transcription of IL-8 in the cells expressing TLR2 only ${ }^{59}$.

TLR1 ECD is consists of 20 predicted LRRs which take part in the mycobacterial PAMP recognition ${ }^{60}$. The central region of the extracellular domain of human TLR1 (LRR 9 to 12) is necessary for the sensing of bacterial lipopeptides ${ }^{32}$. We (unpublished data, bovine TLR1 LRR motif analysis) and others ${ }^{54}$ have found that the central part of TLR1 ECD (LRR9 to LRR 11) is more irregular and prone to missense mutations. In this study a novel mutation Val220Met was observed in LRR10 motif at the $9^{\text {th }}$ amino acid position (Figure 3A). The presence of methionine in this position may disrupts hydrogen bonds in the LRR loop structure that may cause the reduced recognition of PAMPs ${ }^{54}$. The association between mutation at $9^{\text {th }}$ amino acid position in LRR motif and poorlydifferentiated gastric adenocarcinomas was reported recently ${ }^{61}$. The increased incidence of MAP infection in sheep bearing Val220Met mutation (43.2\%; OR - 9.08; Table) was also observed in this study. Significant reduction $(\mathrm{P}<0.05)$ in the cytokine response to TLR1 agonists (LPS and MAP lysate) in moDCs carrying 220Met (LRR10) and 150Gly 
(two residues upstream to LRR8) confirms the adverse effect of mutations in the central ECD of TLR1 (figure 2 panel A and E).

In case of TLR2 the TIR domain is crucial as it forms a TIR-TIR dimerized platforms (TLR1-TLR2 and TLR2-TLR6), which promote homotypic protein-protein interactions and further downstream signaling ${ }^{62}$. Hindered expression of the IFN- $\gamma$, IL-8 and IL-12 in the moDCs carrying homozygous 670Leu (Figure 2 panel B and E) can be due to the impaired dimerization of TLR2-TIR domain with its counterparts. Similar impediment in IL-12, IL-8 and IFN- $\gamma$ production was reported earlier in the Arg677Trp or Arg753Gln mutants ${ }^{62-68}$. Other crucial residues in TLR2-TIR domain (713Ser, 730Asp, 748Arg, 749Phe and 752Leu), were reported previously ${ }^{64}$.

Mutations in extra-LRR region may also impede the pattern recognition. 3D structure of the TLR ECD has demonstrated that LRR forms a loop and the juxtaposition of several loops produce solenoid-like structure ${ }^{54}$. The LRR consensus motif forms the inner core of horseshoe structured ECD, while extra LRR regions forms convex surface. Irregularities and/or mutations in convex surface, for example mutation in $4^{\text {th }}$ residue downstream from LRR motif, may affect PAMP binding onto the TLR horseshoe. The well known human TLR4 mutation, Asp299Gly, is one of the best examples of the mutation at $4^{\text {th }}$ residue downstream from LRR11 (Figure 3B).

In summary, novel mutations found in TLRs in this study might be the potential risk factor that increases the susceptibility to mycobacterial infection. 


\section{Materials and Methods}

\section{Animals}

720 Tsigai sheep, either healthy (healthy cohort) or showing clinical symptoms of paratuberculosis (diseased cohort) were included in this study. The sheep were from four farms located in the same geographic area (eastern Slovakia). These farms were chosen for the present study because of the high incidence (10-18\%) of MAP recorded during paratuberculosis surveillance in the years 2004-2006 (unpublished data). Animals with weight loss and/or chronic diarrhea formed a cohort suspected of paratuberculosis. At least 7 - 8 apparently healthy animals that had close contact with suspected animals were also included in the study. In this way we assured the equal probability of MAP infection on the studied animals. The animal history was recorded and 5-10 $\mathrm{ml}$ of the blood (in duplicate) was collected for the serum and buffy coat separation.

\section{Detection of MAP}

Animals were screened for the presence of anti-MAP antibodies in serum as well as for the presence of IS900 element of MAP in the buffy coat. Antibodies were detected with Pourquier ELISA paratuberculosis kit (Institute Pourquier, France, http://www.institut-pourquier.fr). IS900 based nested PCR for MAP detection was

designed as described previously ${ }^{41}$. The method, sensitivity and specificity of IS900 based PCR are discussed in detail in our previous work ${ }^{41}$. On the basis of PCR and ELISA results, animals were grouped into MAP positive and negative cohorts, and cohorts were subjected to mutation detection in TLR genes. 


\section{Construction of primers and PCR for amplification of TLR gene fragments}

Ectodomain (ECD) of the TLR1 was targeted for mutation detection. Primers were designed (DNASTAR) to amplify a gene fragment covering leucine rich repeats (LRR) 8 to 11 . The primers (TLR1/F 5'-GGAGATACTTATGGGGAAAGAGAA and TLR1/R 5'- GTGTATAGACAAGGCCTTCAGTGA) amplified 402 bp of the gene segment. Conditions for PCR were: initial denaturation at $95^{\circ} \mathrm{C}$ for $3 \mathrm{~min}$, followed by 35 cycles of $94^{\circ} \mathrm{C}$ for $1.0 \mathrm{~min}, 52^{\circ} \mathrm{C}$ for $1 \mathrm{~min} 20 \mathrm{sec}, 72^{\circ} \mathrm{C}$ for $1.0 \mathrm{~min}$ with final extension at $72^{\circ} \mathrm{C}$ for $10 \mathrm{~min}$. Primers for TLR2 were constructed to amplify gene fragments

covering earlier reported Pro681His, Arg677Trp and Arg753Gln mutations ${ }^{15,39}$ located in Toll/Interleukin-1 receptor (TIR) domain. Primers designed for TLR4 spanned both previously described major polymorphism sites, Asp299Gly and Thr399Ile ${ }^{40}$ located in ECD (LRRs 11 to 16). Nucleotide sequences of TLR2 primers were: TLR2/F 5'$\begin{array}{llll}\text { CAGGAGCTGGAGCACTTCAACC } & \text { and }\end{array}$ GTCTCATCCACGGGCCACTCCA, while, TLR4 oligo sequences were: TLR4/F 5'GGGACTGTGCAACCTGACCA and TLR4/R 5'GCTCTAAGCCCATGAAGTTTGAA. PCR conditions for TLR2 gene were: initial denaturation at $94^{\circ} \mathrm{C}$ for $3 \mathrm{~min}$, followed by 35 cycles of $94^{\circ} \mathrm{C}$ for $60 \mathrm{sec} ., 56^{\circ} \mathrm{C}$ for 45 sec, and $72^{\circ} \mathrm{C}$ for $60 \mathrm{sec}$ with final extension at $72^{\circ} \mathrm{C}$ for $10 \mathrm{~min}$. The cycling conditions for TLR4 were similar to TLR2 except annealing temperature $\left(57^{\circ} \mathrm{C}\right)$.

\section{Single strand conformational polymorphism analysis (SSCP)}

Briefly, $5 \mu 1$ of amplified product was mixed with equal amount of loading dye (98\% formamide, $10 \mathrm{mM}$ EDTA, $0.025 \%$ bromophenol blue, $0.025 \%$ xylene-cyanol), subjected to denaturation at $95^{\circ} \mathrm{C}$ for 10 min and then cooled rapidly on ice. Denatured 
single-stranded amplimers were loaded onto $6 \%$ acrylamide/bisacrylamide $(37.5: 1, \mathrm{v} / \mathrm{v}$; Bio-Rad) gels. Electrophoresis was performed using $200 \mathrm{~V}$ at $8^{\circ} \mathrm{C}$ in $0.5 \%$ TBE buffer for 20 hours in the electrophoresis chamber (Ingeny, The Netherlands). Gels were silverstained. Samples were grouped based on SSCP profiles by using Gel-Scan software (BioSciTec, Germany).

\section{DNA Sequencing}

Representative samples from each SSCP genotype were sequenced on an Avant3100 sequencer (Applied Biosystem). The sequences were aligned, then checked for mutations and validated using SeqScape v.2.1 software (Applied Biosystem). Sequences were submitted to the GeneBank (USA) under the accession numbers EF681961 to EF681970. The SNPs were submitted to dbSNP (Genebank) database under the accession numbers: 76880840 to 76880850 and 76878648 to 76878669 .

\section{In-vitro treatment of moDCs with LPS or MAP whole cell lysate}

Representative sheep ( $n=6$ per mutation) carrying mutations in homozygous state and associated with MAP infection (depicted in tables 2 - 4) were included in this phase of the study. Healthy subjects $(n=6)$ without TLR mutations in TLR were served as controls. Monocyte-derived dendritic cells (moDCs) were generated from peripheral blood mononuclear cells as described previously ${ }^{42}$ in Nunc 6-well tissue culture plates (approximately $5 \times 10^{5}$ cells $/$ well in $2 \mathrm{ml}$ of cell suspension). moDCs were either treated with $100 \mu 1$ of LPS $(1 \mathrm{~g} / \mathrm{ml}$; Sigma) or $100 \mu 1$ of MAP whole cell lysate $(\sim 890 \mu \mathrm{g} / \mathrm{ml}$ of protein concentration). As a negative control (no cell activation) moDCs were kept untreated. Cells were incubated at $37^{\circ} \mathrm{C}$ for $4 \mathrm{~h}$ in $5 \% \mathrm{CO}_{2}$ incubator, washed and total RNA was extracted using Purezol RNA isolation kit (Bio-Rad). Complementary DNA 
(cDNA) was synthesized by using iScript cDNA synthesis kit (Bio-Rad). The cDNA was used for real time PCR to examine the effect of treatment of moDCs on cytokine and TLR mRNA expression. moDCs with the mutations and without mutations are designated as mutant moDCs and wildtype moDCs respectively in this report.

\section{Real time PCR for quantification of TLRs and cytokines mRNA expression}

Primers used to amplify cDNAs of the TLRs, cytokines as well as house keeping gene are depicted in table 1. PCR reactions were carried out in triplicate by using iQ SYBR green super mix Kit (Bio-Rad). All PCRs were followed by melting curve analysis (iQ5 thermocycler, Bio-Rad). Melting curve analysis was used to confirm the amplified product purity (confirmation of no non-specific amplicons). Gene expression and comparison was performed using iQ5 software (Bio-Rad).

\section{In silico ovine LRR motif analysis}

Ovine TLR nucleotide sequences obtained in this study were aligned by the ClustalW multiple alignment method (DNASTAR software), translated into putative amino acids and consensus sequences were obtained (BioEdit software). LRR motifs were outlined according to the method described earlier ${ }^{43}$ using PFAM and SSpro4.0 servers ${ }^{44}$.

\section{Statistical analysis}

Possible linkage between mutation in TLR genes and increased MAP infection in cattle was calculated by Odd's ratio (OR) (Win episcope software). 


\section{Acknowledgements}

We thank Mrs. Marta Dancakova and Mrs. Bc. Martina Cepkova for their excellent assistance in the experiment. The work was financed by the research grants AV4/0106/06 and AV/1104/2004 of Slovak Ministry of Education; and VEGA1/3239/06 and VEGA-1/4395/07. We also thank Mr. Frank M. Hodgkins for English language editing. 


\section{References}

1. Medzhitov R, Janeway C, Jr. Innate immune recognition: mechanisms and pathways. Immunol Rev 2000; 173: 89-97.

2. Akira S. Mammalian Toll-like receptors. Curr Opin Immunol 2003; 15(1): 5-11.

3. Barton GM, Medzhitov R. Toll-like receptors and their ligands. Curr Top Microbiol Immunol 2002; 270: 81-92.

4. Beutler B. Innate immune responses to microbial poisons: discovery and function of the Toll-like receptors. Annu Rev Pharmacol Toxicol 2003; 43: 609-28.

5. Takeda K, Kaisho T, Akira S. Toll-like receptors. Annu. Rev. Immunol. 2003; 21: 335-76.

6. Li M, Carpio DF, Zheng Y, Bruzzo P, Singh V, Ouaaz F et al. An essential role of the NF-kappa B/Toll-like receptor pathway in induction of inflammatory and tissue-repair gene expression by necrotic cells. J Immunol 2001; 166(12): 712835 .

7. Medzhitov R. Toll-like receptors and innate immunity. Nat Rev Immunol 2001; 1(2): $135-45$.

8. Gay NJ, Gangloff M. Structure and function of Toll receptors and their ligands. Annu Rev Biochem 2007; 76: 141-65.

9. Alexopoulou L, Holt AC, Medzhitov R, Flavell RA. Recognition of doublestranded RNA and activation of NF-kappaB by Toll-like receptor 3. Nature 2001; 413(6857): 732-8.

10. Diebold SS, Kaisho T, Hemmi H, Akira S, Reis e Sousa C. Innate antiviral responses by means of TLR7-mediated recognition of single-stranded RNA. Science 2004; 303(5663): 1529-31.

11. Heil F, Hemmi H, Hochrein H, Ampenberger F, Kirschning C, Akira S et al. Species-specific recognition of single-stranded RNA via toll-like receptor 7 and 8 . Science 2004; 303(5663): 1526-9.

12. Lund JM, Alexopoulou L, Sato A, Karow M, Adams NC, Gale NW et al. Recognition of single-stranded RNA viruses by Toll-like receptor 7. Proc Natl Acad Sci U S A 2004; 101(15): 5598-603.

13. Hayashi F, Smith KD, Ozinsky A, Hawn TR, Yi EC, Goodlett DR et al. The innate immune response to bacterial flagellin is mediated by Toll-like receptor 5 . Nature 2001; 410(6832): 1099-103. 
14. Hemmi H, Takeuchi O, Kawai T, Kaisho T, Sato S, Sanjo H et al. A Toll-like receptor recognizes bacterial DNA. Nature 2000; 408(6813): 740-5.

15. Ben-Ali M, Barbouche MR, Bousnina S, Chabbou A, Dellagi K. Toll-like receptor 2 Arg677Trp polymorphism is associated with susceptibility to tuberculosis in Tunisian patients. Clin Diagn Lab Immunol 2004; 11(3): 625-6.

16. Heldwein KA, Liang MD, Andresen TK, Thomas KE, Marty AM, Cuesta N et al. TLR2 and TLR4 serve distinct roles in the host immune response against Mycobacterium bovis BCG. J Leukoc Biol 2003; 74(2): 277-86.

17. Janeway CA, Jr., Medzhitov R. Innate immune recognition. Annu Rev Immunol 2002; 20: 197-216.

18. Lien E, Sellati TJ, Yoshimura A, Flo TH, Rawadi G, Finberg RW et al. Toll-like receptor 2 functions as a pattern recognition receptor for diverse bacterial products. J Biol Chem 1999; 274(47): 33419-25.

19. Morre SA, Murillo LS, Bruggeman CA, Pena AS. The role that the functional Asp299Gly polymorphism in the toll-like receptor-4 gene plays in susceptibility to Chlamydia trachomatis-associated tubal infertility. J Infect Dis 2003; 187(2): 341-2; author reply 342-3.

20. Underhill DM, Ozinsky A. Toll-like receptors: key mediators of microbe detection. Curr Opin Immunol 2002; 14(1): 103-10.

21. Underhill DM, Ozinsky A, Smith KD, Aderem A. Toll-like receptor-2 mediates mycobacteria-induced proinflammatory signaling in macrophages. Proc Natl Acad Sci U S A 1999; 96(25): 14459-63.

22. Buwitt-Beckmann U, Heine H, Wiesmuller KH, Jung G, Brock R, Akira S et al. TLR1- and TLR6-independent recognition of bacterial lipopeptides. J Biol Chem 2006; 281(14): 9049-57.

23. Kirschning CJ, Schumann RR. TLR2: cellular sensor for microbial and endogenous molecular patterns. Curr Top Microbiol Immunol 2002; 270: 121-44.

24. Beutler B. Inferences, questions and possibilities in Toll-like receptor signalling. Nature 2004; 430(6996): 257-63.

25. Schumann RR, Tapping RI. Genomic variants of TLR1--it takes (TLR-)two to tango. Eur J Immunol 2007; 37(8): 2059-62.

26. Franchimont D, Vermeire S, El Housni H, Pierik M, Van Steen K, Gustot T et al. Deficient host-bacteria interactions in inflammatory bowel disease? The toll-like 
receptor (TLR)-4 Asp299gly polymorphism is associated with Crohn's disease and ulcerative colitis. Gut 2004; 53(7): 987-92.

27. Hawn TR, Misch EA, Dunstan SJ, Thwaites GE, Lan NT, Quy HT et al. A common human TLR1 polymorphism regulates the innate immune response to lipopeptides. Eur J Immunol 2007; 37(8): 2280-9.

28. Henckaerts L, Pierik M, Joossens M, Ferrante M, Rutgeerts P, Vermeire S. Mutations in pattern recognition receptor genes modulate seroreactivity to microbial antigens in patients with inflammatory bowel disease. Gut 2007; 56(11): 1536-42.

29. Johnson CM, Lyle EA, Omueti KO, Stepensky VA, Yegin O, Alpsoy E et al. Cutting edge: A common polymorphism impairs cell surface trafficking and functional responses of TLR1 but protects against leprosy. J Immunol 2007; 178(12): 7520-4.

30. Schroder NW, Schumann RR. Single nucleotide polymorphisms of Toll-like receptors and susceptibility to infectious disease. Lancet Infect Dis 2005; 5(3): 156-64.

31. Kesh S, Mensah NY, Peterlongo P, Jaffe D, Hsu K, M VDB et al. TLR1 and TLR6 polymorphisms are associated with susceptibility to invasive aspergillosis after allogeneic stem cell transplantation. Ann N Y Acad Sci 2005; 1062: 95-103.

32. Omueti KO, Mazur DJ, Thompson KS, Lyle EA, Tapping RI. The polymorphism P315L of human toll-like receptor 1 impairs innate immune sensing of microbial cell wall components. J Immunol 2007; 178(10): 6387-94.

33. Thuong NT, Hawn TR, Thwaites GE, Chau TT, Lan NT, Quy HT et al. A polymorphism in human TLR2 is associated with increased susceptibility to tuberculous meningitis. Genes Immun 2007; 8(5): 422-8.

34. Bochud PY, Hawn TR, Aderem A. Cutting edge: a Toll-like receptor 2 polymorphism that is associated with lepromatous leprosy is unable to mediate mycobacterial signaling. J Immunol 2003; 170(7): 3451-4.

35. Bochud PY, Hawn TR, Siddiqui MR, Saunderson P, Britton S, Abraham I et al. Toll-like receptor 2 (TLR2) polymorphisms are associated with reversal reaction in leprosy. J Infect Dis 2008; 197(2): 253-61.

36. Khor CC, Chapman SJ, Vannberg FO, Dunne A, Murphy C, Ling EY et al. A Mal functional variant is associated with protection against invasive pneumococcal disease, bacteremia, malaria and tuberculosis. Nat Genet 2007; 39(4): 523-8. 
37. Tabel Y, Berdeli A, Mir S. Association of TLR2 gene Arg753Gln polymorphism with urinary tract infection in children. Int J Immunogenet 2007; 34(6): 399-405.

38. Fukusaki T, Ohara N, Hara Y, Yoshimura A, Yoshiura K. Evidence for association between a Toll-like receptor 4 gene polymorphism and moderate/severe periodontitis in the Japanese population. J Periodontal Res 2007; 42(6): 541-5.

39. Berdeli A, Celik HA, Ozyurek R, Dogrusoz B, Aydin HH. TLR-2 gene Arg $753 \mathrm{Gln}$ polymorphism is strongly associated with acute rheumatic fever in children. J Mol Med 2005; 83(7): 535-41.

40. Hong J, Leung E, Fraser AG, Merriman TR, Vishnu P, Krissansen GW. TLR2, TLR4 and TLR9 polymorphisms and Crohn's disease in a New Zealand Caucasian cohort. J Gastroenterol Hepatol 2007; 22(11): 1760-6.

41. Bhide M, Chakurkar E, Tkacikova L, Barbuddhe S, Novak M, Mikula I. IS900PCR-based detection and characterization of Mycobacterium avium subsp. paratuberculosis from buffy coat of cattle and sheep. Vet Microbiol 2006; 112(1): $33-41$.

42. Raymond CR, Wilkie BN. Toll-like receptor, MHC II, B7 and cytokine expression by porcine monocytes and monocyte-derived dendritic cells in response to microbial pathogen-associated molecular patterns. Vet Immunol Immunopathol 2005; 107(3-4): 235-47.

43. Matsushima N, Tanaka T, Enkhbayar P, Mikami T, Taga M, Yamada K et al. Comparative sequence analysis of leucine-rich repeats (LRRs) within vertebrate toll-like receptors. BMC Genomics 2007; 8: 124.

44. Cheng J, Randall AZ, Sweredoski MJ, Baldi P. SCRATCH: a protein structure and structural feature prediction server. Nucleic Acids Res 2005; 33(Web Server issue): W72-6.

45. Ferwerda G, Kullberg BJ, de Jong DJ, Girardin SE, Langenberg DM, van Crevel $\mathrm{R}$ et al. Mycobacterium paratuberculosis is recognized by Toll-like receptors and NOD2. J Leukoc Biol 2007; 82(4): 1011-8.

46. Taylor DL, Zhong L, Begg DJ, de Silva K, Whittington RJ. Toll-like receptor genes are differentially expressed at the sites of infection during the progression of Johne's disease in outbred sheep. Vet Immunol Immunopathol 2008; 124(1-2): $132-51$.

47. Means TK, Lien E, Yoshimura A, Wang S, Golenbock DT, Fenton MJ. The CD14 ligands lipoarabinomannan and lipopolysaccharide differ in their requirement for Toll-like receptors. J Immunol 1999; 163(12): 6748-55. 
48. Brightbill HD, Libraty DH, Krutzik SR, Yang RB, Belisle JT, Bleharski JR et al. Host defense mechanisms triggered by microbial lipoproteins through toll-like receptors. Science 1999; 285(5428): 732-6.

49. Krutzik SR, Ochoa MT, Sieling PA, Uematsu S, Ng YW, Legaspi A et al. Activation and regulation of Toll-like receptors 2 and 1 in human leprosy. Nat Med 2003; 9(5): 525-32.

50. Means TK, Wang S, Lien E, Yoshimura A, Golenbock DT, Fenton MJ. Human toll-like receptors mediate cellular activation by Mycobacterium tuberculosis. $J$ Immunol 1999; 163(7): 3920-7.

51. Wills-Karp M. IL-12/IL-13 axis in allergic asthma. J Allergy Clin Immunol 2001; 107(1): 9-18.

52. Werling D, Hope JC, Howard CJ, Jungi TW. Differential production of cytokines, reactive oxygen and nitrogen by bovine macrophages and dendritic cells stimulated with Toll-like receptor agonists. Immunology 2004; 111(1): 41-52.

53. von Aulock S, Schroder NW, Traub S, Gueinzius K, Lorenz E, Hartung T et al. Heterozygous toll-like receptor 2 polymorphism does not affect lipoteichoic acidinduced chemokine and inflammatory responses. Infect Immun 2004; 72(3): 182831.

54. Bell JK, Mullen GE, Leifer CA, Mazzoni A, Davies DR, Segal DM. Leucine-rich repeats and pathogen recognition in Toll-like receptors. Trends Immunol. 2003; 24(10): 528-33.

55. Hamann L, Kumpf O, Muller M, Visintin A, Eckert J, Schlag PM et al. A coding mutation within the first exon of the human MD-2 gene results in decreased lipopolysaccharide-induced signaling. Genes Immun. 2004; 5(4): 283-8.

56. Re F, Strominger JL. Toll-like receptor 2 (TLR2) and TLR4 differentially activate human dendritic cells. J Biol Chem 2001; 276(40): 37692-9.

57. de Waal Malefyt R, Figdor CG, Huijbens R, Mohan-Peterson S, Bennett B, Culpepper J et al. Effects of IL-13 on phenotype, cytokine production, and cytotoxic function of human monocytes. Comparison with IL-4 and modulation by IFN-gamma or IL-10. J Immunol 1993; 151(11): 6370-81.

58. de Waal Malefyt R, Figdor CG, de Vries JE. Effects of interleukin 4 on monocyte functions: comparison to interleukin 13. Res Immunol 1993; 144(8): 629-33. 
59. Dabbagh K, Dahl ME, Stepick-Biek P, Lewis DB. Toll-like receptor 4 is required for optimal development of Th2 immune responses: role of dendritic cells. $J$ Immunol 2002; 168(9): 4524-30.

60. Ohara T, Morishita T, Suzuki H, Hibi T. Heterozygous Thr 135 Ala polymorphism at leucine-rich repeat (LRR) in genomic DNA of toll-like receptor 4 in patients with poorly-differentiated gastric adenocarcinomas. Int. J. Mol. Med. 2006; 18(1): 59-63.

61. Xu Y, Tao X, Shen B, Horng T, Medzhitov R, Manley JL et al. Structural basis for signal transduction by the Toll/interleukin-1 receptor domains. Nature 2000; 408(6808): 111-5.

62. Gautam JK, Ashish, Comeau LD, Krueger JK, Smith MF, Jr. Structural and functional evidence for the role of the TLR2 DD loop in TLR1/TLR2 heterodimerization and signaling. J Biol Chem 2006; 281(40): 30132-42.

63. Kang TJ, Lee SB, Chae GT. A polymorphism in the toll-like receptor 2 is associated with IL-12 production from monocyte in lepromatous leprosy. Cytokine 2002; 20(2): 56-62.

64. Kang TJ, Yeum CE, Kim BC, You EY, Chae GT. Differential production of interleukin-10 and interleukin-12 in mononuclear cells from leprosy patients with a Toll-like receptor 2 mutation. Immunology 2004; 112(4): 674-80.

65. Schroder NW, Diterich I, Zinke A, Eckert J, Draing C, von Baehr V et al. Heterozygous Arg753Gln polymorphism of human TLR-2 impairs immune activation by Borrelia burgdorferi and protects from late stage Lyme disease. $J$ Immunol 2005; 175(4): 2534-40.

66. Mrabet-Dahbi S, Dalpke AH, Niebuhr M, Frey M, Draing C, Brand S et al. The Toll-like receptor 2 R753Q mutation modifies cytokine production and Toll-like receptor expression in atopic dermatitis. J Allergy Clin Immunol 2008; 121(4): 1013-9.

67. Woehrle T, Du W, Goetz A, Hsu HY, Joos TO, Weiss M et al. Pathogen specific cytokine release reveals an effect of TLR2 Arg753Gln during Candida sepsis in humans. Cytokine 2008; 41(3): 322-9.

68. Tao X, Xu Y, Zheng Y, Beg AA, Tong L. An extensively associated dimer in the structure of the C713S mutant of the TIR domain of human TLR2. Biochem Biophys Res Commun 2002; 299(2): 216-21. 
Table 1. Primers used in this study

\begin{tabular}{|c|c|c|c|}
\hline Gene & Sequence (5'- 3') & $\begin{array}{l}\text { Amplicon } \\
\text { length } \\
\text { (bp) }\end{array}$ & $\begin{array}{l}\text { Annealing } \\
\text { temperature } \\
\quad\left({ }^{\circ} \mathrm{C}\right)\end{array}$ \\
\hline $\begin{array}{l}\text { IS900- MAP } \\
\text { (extrernal) }\end{array}$ & $\begin{array}{l}\text { F- AGGGTGTTCGGGGCCGTCGCTTAG } \\
\text { R- TGAGGTCGATCGCCCACGTGACCT }\end{array}$ & 406 & 56.5 \\
\hline $\begin{array}{l}\text { IS900- MAP } \\
\text { (internal) }\end{array}$ & $\begin{array}{l}\text { F- ATGTGGTTGCTGTGTTGGATGG } \\
\text { R- CCGCCGCAATCAACTCCAG }\end{array}$ & 298 & 63.0 \\
\hline TLR1 & $\begin{array}{l}\text { F - GGAGATACTTATGGGGAAAGAGAA } \\
\text { R - GTGTATAGACAAGGCCTTCAGTGA }\end{array}$ & 402 & 52.0 \\
\hline TLR2 & $\begin{array}{l}\text { F - CAGGAGCTGGAGCACTTGTACC } \\
\text { R - GTCTCATCCACGGGCCAGACCA }\end{array}$ & 362 & 56.0 \\
\hline TLR4 & $\begin{array}{l}\text { F - GGGACTGTGCAACCTGACCA } \\
\text { R - GCTCTAAGCCCATGAAGTTTGAA }\end{array}$ & 434 & 53.0 \\
\hline IL-4 & $\begin{array}{l}\text { F - CCCAGCGCTGGTCTGCTTACT } \\
\text { R - GCTTGCCAGGCTGCTGAGATT }\end{array}$ & 283 & 57.4 \\
\hline IL-8 & $\begin{array}{l}\text { F - TTGGCCGCTTTCCTGCTCT } \\
\text { R - AAATGCCTGCACAACCTTCTGC }\end{array}$ & 249 & 55.2 \\
\hline IL-10 & $\begin{array}{l}\text { F - AGCCGAGATGCCAGCACCCTGTC } \\
\text { R - AGCTTCTCCCCCAGCGAGTTCACG }\end{array}$ & 293 & 61.0 \\
\hline IL-12p35 & $\begin{array}{l}\text { F - GAGCCTGCCCACCACCACA } \\
\text { R - GGAAGCCAGGCAACTCTCATT }\end{array}$ & 226 & 56.4 \\
\hline IFN- $\gamma$ & $\begin{array}{l}\text { F - CTAAGGGTGGGCCTCTTTTCTC } \\
\text { R - CATCCACCGGAATTTGAATCAG }\end{array}$ & 237 & 53.2 \\
\hline$\beta$ actin & $\begin{array}{l}\text { F - ACTGGGACGACATGGAGAG } \\
\text { R - AGGAAGGAAGGCTGGAAGAG }\end{array}$ & 568 & 54.0 \\
\hline
\end{tabular}


Table 2. Missense mutations in the ovine TLR1

\begin{tabular}{lllll}
\hline & & $\begin{array}{l}\text { Wild type } \\
\text { frequency }\end{array}$ & $\begin{array}{l}\text { frequency of } \\
\text { mutation } \\
\text { in heterozygous } \\
\text { state }\end{array}$ & $\begin{array}{l}\text { frequency of } \\
\text { mutation } \\
\text { in homozygous } \\
\text { state }\end{array}$ \\
\hline $418 \mathrm{~A}>\mathrm{G}$ & Lys140Glu & $0.997(11.4 \%)$ & 0 & $0.002(0 \%)$ \\
$431 \mathrm{~A}>\mathrm{T}$ & Asn144Ile & $0.997(11.4 \%)$ & 0 & $0.002(0 \%)$ \\
$448 \mathrm{~A}>\mathrm{G}$ & Ser150Gly & $0.897(8.38 \%)$ & 0 & $0.10(43.2 \%, \mathbf{9 . 0 8})$ \\
$508 \mathrm{~T}>\mathrm{C}$ & Ser170Pro & $0.997(11.4 \%)$ & 0 & $0.002(0 \%)$ \\
$517 \mathrm{G}>\mathrm{R}$ & Glu173[Lys, Glu] & $0.897(8.38 \%)$ & $0.10(43.2 \%, 9.08)$ & 0 \\
\hline $601 \mathrm{~A}>\mathrm{T}$ & Ile201Phe & $0.997(11.4 \%)$ & 0 & $0.002(0 \%)$ \\
$603 \mathrm{~T}>\mathrm{C}$ & Ile201Phe & $0.997(11.4 \%)$ & 0 & $0.002(0 \%)$ \\
$658 \mathrm{~A}>\mathrm{G}$ & Val220Met & $0.897(8.38 \%)$ & 0 & $0.102(43.2 \%, \mathbf{9 . 0 8})$ \\
\hline
\end{tabular}


Table 3. Missense mutations in the ovine TLR2

\begin{tabular}{|c|c|c|c|c|}
\hline & & $\begin{array}{l}\text { Wild type } \\
\text { frequency }\end{array}$ & $\begin{array}{l}\text { frequency of } \\
\text { mutation } \\
\text { in heterozygous } \\
\text { state }\end{array}$ & $\begin{array}{l}\text { frequency of } \\
\text { mutation } \\
\text { in homozygous } \\
\text { state }\end{array}$ \\
\hline $1985 \mathrm{~A}>\mathrm{W}$ & Glu662[Glu,Val] & $0.94(21 \%)$ & $0.06(4.7 \%)$ & 0 \\
\hline $2008 \mathrm{~A}>\mathrm{Y}$ & Phe670[Leu,Phe] & $0.55(6.5 \%)$ & $0.25(25 \%, 4.5)$ & $0.20(7.6 \%, 1.1)^{1}$ \\
\hline $2012 \mathrm{~A}>\mathrm{M}$ & Lys671[Asn,Thr] & $0.99(11.4 \%)$ & $0.01(0 \%)$ & 0 \\
\hline $2013 \mathrm{G}>\mathrm{T}$ & Lys671[Asn,Thr] & $0.99(11.4 \%)$ & 0 & $0.01(0 \%)$ \\
\hline $2028 \mathrm{G}>\mathrm{S}$ & Lys676[Asn,Lys] & $0.99(11.4 \%)$ & $0.01(0 \%)$ & 0 \\
\hline $2037 \mathrm{~T}>\mathrm{Y}$ & Leu679Phe & $0.57(6.3 \%)$ & $0.35(19.9 \%, 2.01)$ & $0.08(10.3 \%, 1.36)$ \\
\hline $2038 \mathrm{G}>\mathrm{A}$ & Val680Ile & $0.998(11.4 \%)$ & 0 & $0.002(0 \%)$ \\
\hline $2040 \mathrm{C}>\mathrm{T}$ & Val680Ile & $0.998(11.4 \%)$ & 0 & $0.002(0 \%)$ \\
\hline $2090 \mathrm{G}>\mathrm{R}$ & Arg697[His,Arg] & $0.997(12.9 \%)$ & $0.001(0 \%)$ & $0.003(0 \%)$ \\
\hline $2111 \mathrm{C}>\mathrm{y}$ & Ser704[Ser,Leu] & $0.998(11.4 \%)$ & $0.002(0 \%)$ & 0 \\
\hline $2117 \mathrm{G}>\mathrm{A}$ & Ser706Asn & $0.995(11.4 \%)$ & 0 & $0.005(0 \%)$ \\
\hline $2126 \mathrm{G}>\mathrm{A}$ & Arg709Lys & $0.997(11.4 \%)$ & 0 & $0.003(0 \%)$ \\
\hline $2233 \mathrm{G}>\mathrm{R}$ & Val745[Ile, Val] & $0.995(11.4 \%)$ & $0.001(0 \%)$ & $0.004(0 \%)$ \\
\hline $2276 \mathrm{G}>\mathrm{A}$ & Arg759Lys & $0.995(11.4 \%)$ & 0 & $0.005(0 \%)$ \\
\hline $2296 \mathrm{G}>\mathrm{A}$ & Val766Thr & $0.998(11.4 \%)$ & 0 & $0.002(0 \%)$ \\
\hline $2297 \mathrm{~T}>\mathrm{C}$ & Val766Thr & $0.998(11.4 \%)$ & 0 & $0.002(0 \%)$ \\
\hline
\end{tabular}


Table 4. Missense mutations in the ovine TLR4

\begin{tabular}{|c|c|c|c|c|}
\hline & & $\begin{array}{l}\text { Wild type } \\
\text { frequency }\end{array}$ & $\begin{array}{l}\text { frequency of } \\
\text { mutation } \\
\text { in heterozygous } \\
\text { state }\end{array}$ & $\begin{array}{l}\text { frequency of } \\
\text { mutation } \\
\text { in homozygous } \\
\text { state }\end{array}$ \\
\hline $881 \mathrm{G}>\mathrm{R}$ & Ser294[Ser,Asn] & $0.84(12.6 \%)$ & $0.14(5.7 \%)$ & $0.02(0 \%)$ \\
\hline $883 \mathrm{~A}>\mathrm{R}$ & Lys295[Lys,Glu] & $0.84(12.6 \%)$ & $0.14(5.7 \%)$ & $0.02(0 \%)$ \\
\hline $892 \mathrm{~T}>\mathrm{Y}$ & $\operatorname{Trp} 298[\operatorname{Trp}, \operatorname{Arg}]$ & $0.84(12.6 \%)$ & $0.14(5.7 \%)$ & $0.02(0 \%)$ \\
\hline $934 \mathrm{G}>\mathrm{A}$ & Val312Met & $0.998(11.4 \%)$ & 0 & $0.002(0 \%)$ \\
\hline $955 \mathrm{~T}>\mathrm{C}$ & Ser319Pro & $0.998(11.4 \%)$ & 0 & $0.002(0 \%)$ \\
\hline $1029 \mathrm{~T}>\mathrm{K}$ & Asp343[Glu,Asp] & $0.993(11.4 \%)$ & $0.007(0 \%)$ & 0 \\
\hline $1032 \mathrm{G}>\mathrm{S}$ & Lys344[Asn,Lys] & $0.87(12.6 \%)$ & $0.12(3.5 \%)$ & $0.012(0 \%)$ \\
\hline $1045 \mathrm{~A}>\mathrm{G}$ & Lys349Glu & $0.998(11.4 \%)$ & 0 & $0.002(0 \%)$ \\
\hline $1052 \mathrm{G}>\mathrm{R}$ & Arg351[His,Arg] & $0.87(12.3 \%)$ & $0.12(5.8 \%)$ & $0.012(0 \%)$ \\
\hline $1066 \mathrm{~T}>\mathrm{Y}$ & Phe356[Leu,Phe] & $0.36(14.3 \%)$ & $0.52(8.2 \%)$ & $0.12(16.4 \%, 1.64)^{1}$ \\
\hline $1088 \mathrm{~A}>\mathrm{R}$ & Asp363[Asp,Gly] & $0.84(12.5 \%)$ & $0.14(5.7 \%)$ & $0.02(0 \%)$ \\
\hline $1091 \mathrm{~T}>\mathrm{Y}$ & Val364[Val,Ala] & $0.84(12.5 \%)$ & $0.14(5.7 \%)$ & $0.02(0 \%)$ \\
\hline $1097 \mathrm{C}>\mathrm{S}$ & Thr366[Thr,Ser] & $0.84(12.5 \%)$ & $0.14(5.7 \%)$ & $0.02(0 \%)$ \\
\hline $1166 \mathrm{G}>\mathrm{S}$ & Ser389[Thr,Ser] & $0.998(11.4 \%)$ & $0.001(0 \%)$ & 0 \\
\hline $1183 \mathrm{G}>\mathrm{K}$ & Asp395[Asp,Tyr] & $0.84(12.5 \%)$ & $0.14(6 \%)$ & $0.002(0 \%)$ \\
\hline
\end{tabular}




\section{Footnote for tables 2 to 4}

$\mathbf{1}$ The first value in the parenthesis indicate percent animals infected with MAP that carries given point mutation, the second value (bold-italics) is the odd ratio (OR) indicating the possible linkage between point mutation and increased susceptibility to MAP infection. 


\section{Titles and legends to figures}

Figure 1. Activation of TLRs in mutant and wild type (WT) moDCs after activation by LPS or MAP whole cell lysate

Relative fold expressions of TLR mRNA by activated mutant and wild type moDCs. The cells were either activated by LPS ( $\square$ ) or MAP whole cell lysate ( $\square$ ).

Figure 2. Expression of cytokine mRNA in the activated mutant and wild type moDCs

Comparative relative fold expressions of cytokine mRNA by activated mutant (A to D) and wild type (E) moDCs. The cells were either activated by LPS ( $\square$ ) or MAP whole cell lysate ( $\square$ ). $\beta$-actin served as reference gene. Panel A - TLR1-Gly150, Met220; panel B TLR2-Leu670; panel C - TLR2-Phe679; panel D - TLR4-Leu356 and panel E - wild type.

Figure 3. Comparative amino acid sequences of human and sheep LRR motif of

\section{TLR1 and TLR4}

Panel A (TLR1) and B (TLR4). Irregularities in the LRR motifs (LxxLxLxxNxL) are depicted with underlined letters; differences between human and ovine LRR domains are indicated with and mutations TLR1-Ser150Gly and Val220Met are highlighted with Known mutations in human TLR4 - Asp299Gly and Thr399Ile are located in extra LRR $\operatorname{motif}(*$, panel B).

Panel C. Representative electropherogram depicting nucleotide sequences of mutant (upper, 220Met) and wild type (lower, 220Val) TLR1-LRR10. Codons encoding methionine or valine are framed. 


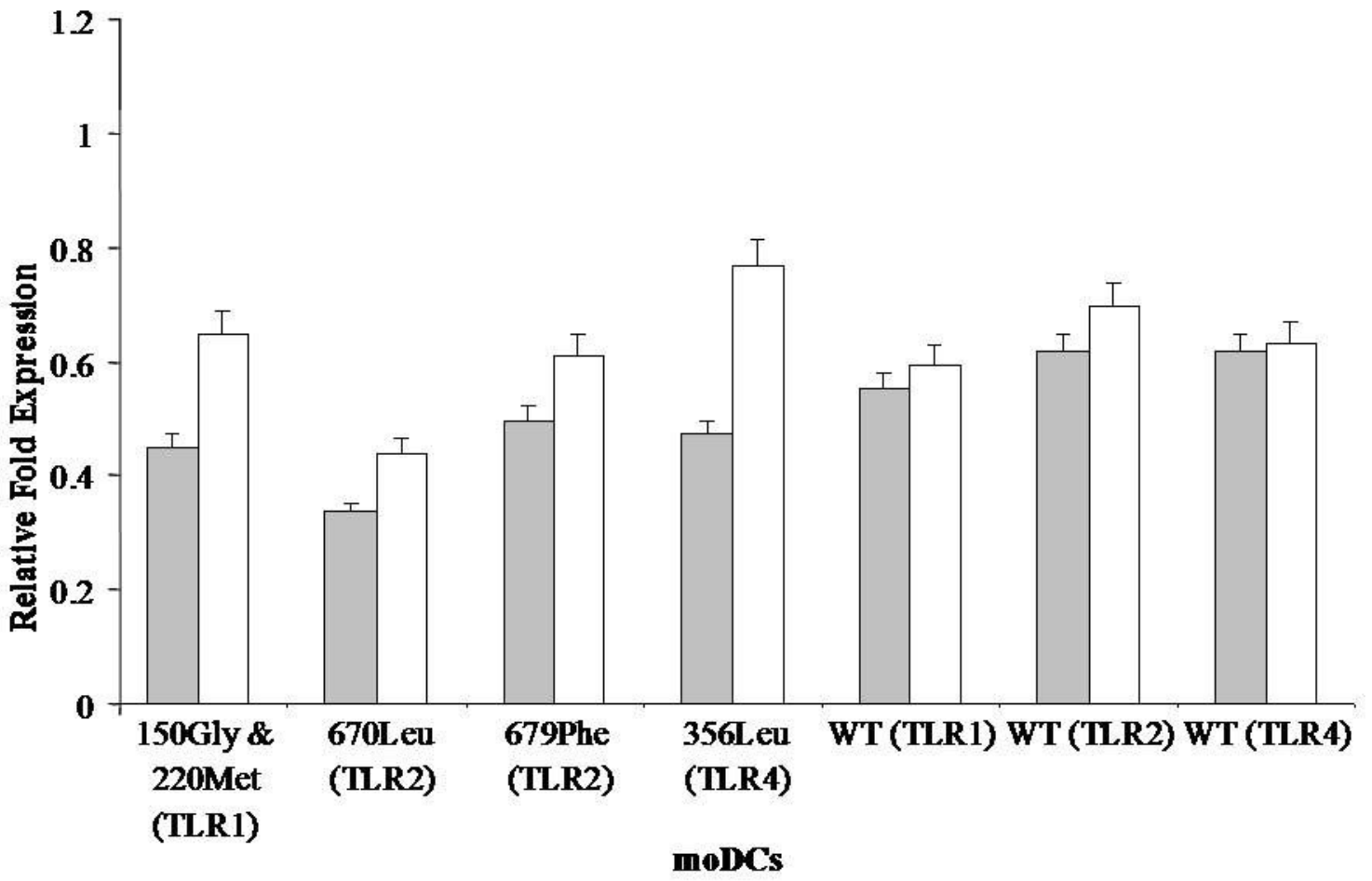




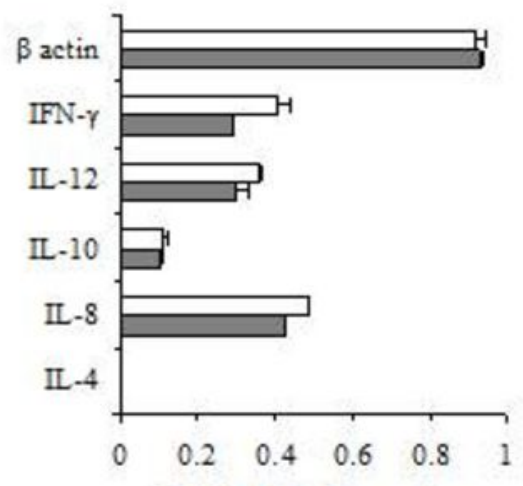

Relative Fold Expression

(C)

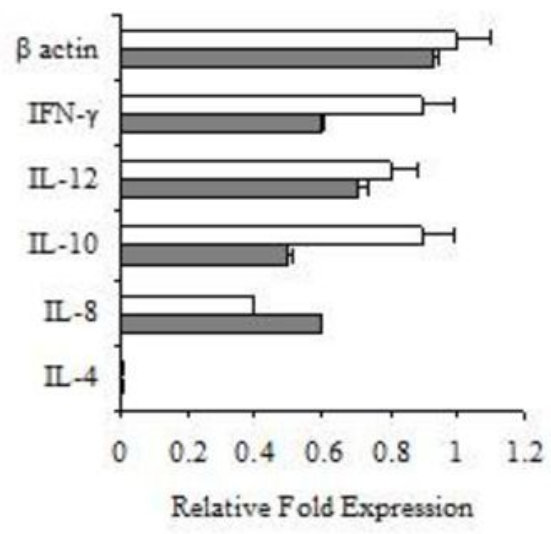

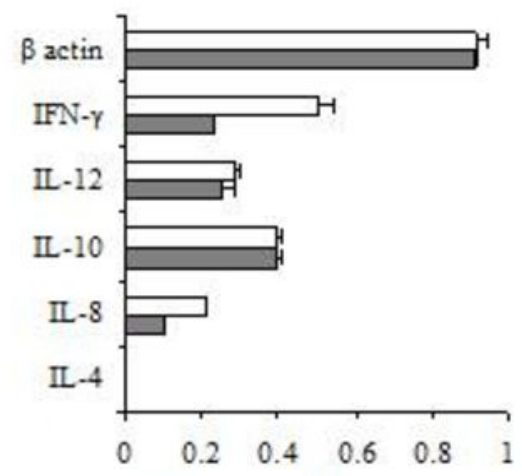

Relative Fold Expression

(D)

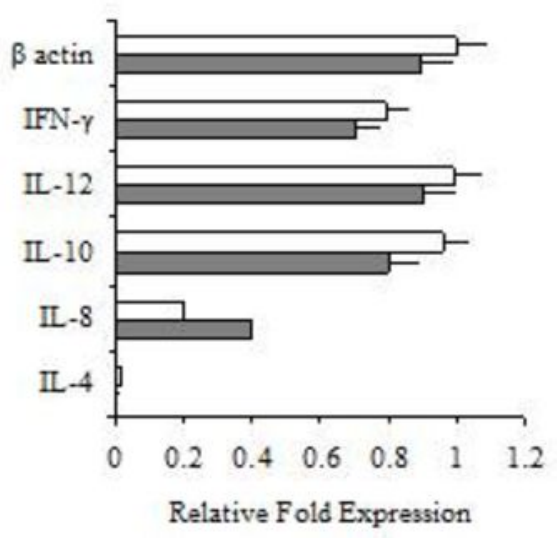

(E)

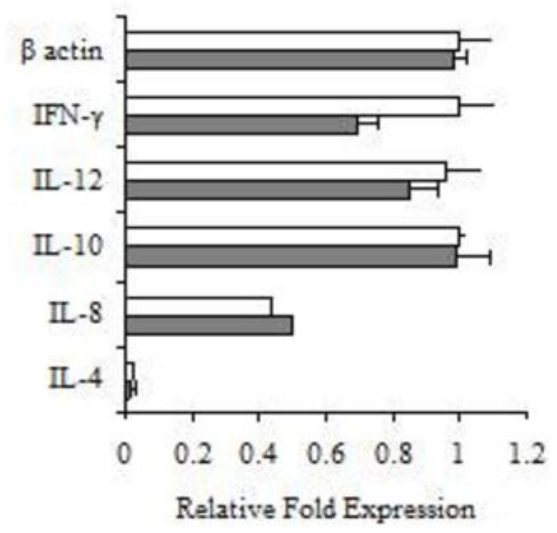


KEFHF I LDVSV K T
KKFHFNLDVSV(S/G) T
TVSLELSNIKC̣
TVOO

VLEDNKCSY FLS I LAKLQTNPK LSSLTUNNIET VDDNGCSYFENVLSKLQKNSR LSNLTLNNIE!

TWNSFIRILQLWWHTT VWYSSISN V KL TWNSFITLQLVWRTN

QGQLDFRDFDYSGTS QGYLDSRDFDYSDTS
I EYFSISN(V/M)KL

LKALSIHKVV LKALSIHQVV $\underline{\mathbf{S}}$
Human LRR8 Sheep LRR 8

Human LRR9 Sheep LRR9

Human LRR10 Sheep LRR10

Human LRR11 Sheep LRR11 
LXXLXLXXNXL TLR4

*

YLDD I I DLFNCLNT FSRNDTDLFNCLAN

ERVKDFSYNFG GSLQAL LKDFR

GQFPTLKLKS DKFPALKLRS

GNAFSEVDLPS ASSFT KTE LPS

SFKGCCSQSDFGT I S SFKSCCS HTY FGTTN
VSSFSLVSVT

VSVI S LLS ISL 000000

WQHLE LVNCKP WQHLEM INCDF

LKRLTFTSNKG LKKFVFTDNKG $000 \%$

LEFLDLSRNGL LQYLDLKRNHL 0000

LKYLDLSFNGV LKHLDLSFNDV 0
Human LRR12 Sheep LRR12

Human LRR13 Sheep LRR13

Human LRR14 Sheep LRR14

Human LRR15 Sheep LRR15

Human LRR16 Sheep LRR16 
